\title{
COMMUNITY PARTICIPATION AND PERFORMANCE OF FRUIT EXPORT PROJECT IN RWANDA: ACASE OF NAEB FRUIT PROJECT
}

\author{
Daniel KAREMERA ${ }^{1 *}$, Mercylin KAMANDE ${ }^{2}$, \\ ${ }^{*}$ School of Business and Economics, Business Administration (MBA), Project Management, Mount Kenya University, \\ Kigali, Rwanda \\ ${ }^{2}$ Mount Kenya University
}

*Corresponding Author: -

\begin{abstract}
: -
Fruit export project do not work properly due to low level of community participation in the early levels of the project such as NAEB fruit export project. It is in this context that the researcher wants to conduct research on the effect of participation of community in implementation of fruit export project with a case of the NAEB fruit export project. Descriptive research design was applied to 395 beneficiaries that gives 123 respondents as per Krejcie and Morgan (1970) and other 21 respondents selected by census sampling method to make 144 informants that was used to get information from the field with the help of interview schedule and selfadministered questionnaire. The information attained was processed through SPSS version 21.0 to generate descriptive and inferential statistics though mean, standard deviation, correlation and linear regression analysis and the results were presented in figures and others in tables. The results of the first objective of the study concerning the community empowerment and performance of NAEB fruit export project have shown an overall mean of 1.481 have strongly tendency of confirming the contribution of community empowerment on performance of project. The results of second objective also showed that the overall perception of 1.811 confirms that the effect of collective decision making on performance of $N A E B$ fruit export project. The third objective of the study have demonstrated a positive and significant relationship between community participation and performance of NAEB fruit export project for instance relationship between community empowerment and stakeholder welfare improvement $(r=0.868$ and sig=0.00), between collective decision making and profitability of project $(r=0.767$ and sig=0.00), between joint consultation and profitability of project $(r=0.907$ and sig=0.00) because all calculated $p$-values are less than 0.01 level of significance. The regression analysis model which is $Y=\beta 0+\beta 1 X 1+\beta 2 X 2+\beta 3 X 3+\varepsilon$ have become $Y=.016+.1 .314 x 1+1.123 \times 2+.827 \times 3$ which revealed that there is a positive significant relationship between community participation and stakeholder satisfaction of NAEB Fruit Project because all regression coefficients; community empowerment and stakeholder satisfaction with ( $b=1.314$ and sig=0.00), collective decision making and stakeholder satisfaction with $(b=1.123$ and sig=0.00), and joint consultation and stakeholder satisfaction has a positive relationship $(b=0.827$ and sig $=0.00)$ are positive while calculated sig-values are less than 0.05 level of significance. Thus, the researcher would like to recommend the community concerned with NAEB fruit export project to analyze the weaknesses and strengths of their project to ensure that not only the external market is target so that the internal market also can be targeted to ensure their performance even in the case of business shut down like the issue of lockdown of COVID-19 or any other problem that can hinder them to access the external market for fruit export..
\end{abstract}

Keywords: - Community participation, Performance, Fruit export project, NAEB and Rwanda

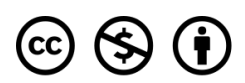




\section{INTRODUCTION}

Community participation in rural development is extensively identified as the primary operational precept of rural development, though debates on this thought are enthusiastic. Beneficiaries of projects run in the community have been seen as consumers of services and their role in rural development are viewed as less significance. Community participation has been limited to consultations, managing to stabilize the innovative and manageable capacities of community collaborators at all tiers of society. Community development initiatives are frequently proven to be participatory if they can be proven to consist of community views and signify problems of the community (Kai \& Greenwood, 2003).

Research pursued by Thwala (2010) on participation of community and rural water project performance in South Africa emphasized that the strength of community participation lays at information sharing, decision making, consultation and initiation of actions to empower community for project performance. Hence, it was also proved that community empowerment affects performance of project, between community participation and building beneficiary capacity, and between increasing project effectiveness and project performance.

Participation of community does not happen by chance (Samah \& Aref, 2009). However, the practices of participatory development are not well cultured in Africa due to lack of well-defined structure of community participation as the main challenging problem of development. The participation of people in the project designed for them has not yet attained the admirable levels to qualify as the project that enhances full participation of community members in project activities (Thwala, 2010).

The participation of the community as primary stakeholders during the implementation phase of the project has been noted to be lackluster, in spite of the fact that local participation was made to be a key requirement in the project implementation framework (Samah \& Aref, 2009). It is observed that the primary beneficiaries have apparently been unable to effectively self- mobilize, and implement the non- technical activities of the project, as required. As such, the current level of participation is regarded to be non-conducive for project sustainability. It is therefore feared that the continued community alienation members would make the project unsustainable and would likely increase poverty, household food insecurity and economic stagnation, thus working against the noble objectives of the project.

In the case of this study concerning participation of community and performance of fruit export project; it was observed that there are fewer studies conducted in both Africa and East Africa, particularly in Rwanda when it goes to this field of study, despite the very minimal empirical studies that were conducted in the region to mention like Kimutai and Awuori (2016) on community participation and performance of fruit exporting firms in Kenya. The literatures have shown that there are no studies in Rwanda that aimed at studying the relationship between participation of community and performance of fruit export project in Rwanda. Though, it was observed that community participation in enhancing performance of rural project is still a myth in most parts of developing countries, Rwanda inclusive. It is in this sense that the researcher aims to carry out research on participation of community and performance fruit export project in Rwanda, particularly in NAEB fruit export project.

\subsection{Objectives of the study \\ 1.1.1 General objective}

The main objective of this research was to examine the role of participation of community on performance of export fruits project in Rwanda.

\subsubsection{Specific objectives}

(i) To assess the contribution of community empowerment on performance of NAEB fruit export project in Rwanda;

(ii) To examine the effect of collective decision making on performance of NAEB fruit export project in Rwanda;

(iii) To establish the relationship between joint consultation and performance of NAEB fruit export project in Rwanda.

\section{Review of Literature \\ 2.1 Empirical Literature}

The previous studies conducted in this field of community participation and project performance such as in Zimbabwe by Cleaver (2009) discovered that empowerment and long-term effectiveness of participatory techniques is complex. The challenge of community in the mobilization of vital resources, through fundraising by means of individuals in the community and via the budget of authority's officials, notably affected the sustainability of the project. Narayan (2015) analyzed the classes of 121 rural water provide projects funded by distinct groups in forty-nine developing nations and discovered that the involvement of local communities used to be a necessary thing for effectiveness and sustainability. To strengthen the community capacity a framework for development project was designed (Freudenberg, 2004); which is attained by assessing the environment and the capacity of the community involved in political systems, culture and economic dynamics and in the manner in which these factors affect participation and support the community. The developmental framework helps the project team to recognize manifestations of the behaviors in the involved community.

The study conducted by Alyse and Akehur (2003) revealed performance of fruit export project as subjective and objective measures if it is viewed to recommend that every effect has to do with absolute indications of thorough performance, while subjective measures are related to the overall performance of the project in relation to its 
competitors or relative business expectations. Another study conducted by Kashish and Vikrant (2017) on production of fruit for export focused on satisfying customers and increasing value that affect positive the performance of market in business products through market intelligence.

Thwala (2010) researched on community participation for performance of rural water supply project at Jeppes Reefs in South Africa. The findings showed a relationship between community empowerment and project performance, community participation and building beneficiary capacity, increasing project effectiveness and performance. Another study conducted by Thwala (2001) indicated that the strength of community participation lays at information sharing, decision making, consultation and initiation of actions to empower community for project performance. Another study conducted by Abbot (2011) on community participation in development in Johannesburg have revealed that the performance of fruit export project that support in recruiting more villagers to participate in the process of producing more fruit to support market, community empowerment, building beneficiary capacity and project cost sharing.

The study conducted on the significance of community participation in an ongoing construction of a college in Tanzania in Mlali and Mzumbe, Morogoro by Mnaranara (2010) has shown that community participation plays an important role that leads to community ownership that enhances project performance. The study also emphasizes the significance and usefulness of knowledge, skills, and ride if solely the neighborhood has had additional information to take on the intervention, even in minor activities. The session additionally supported the magnitude of the nearby mobilization lets individuals who are selected to make decision to reflect on consideration on it to be related to their social and financial development.

Wanjohi (2010) while studying performance of CBOs, argued that adopting more radical processes to tackling the problems of community-based project sustainability: new modes of sustainability primarily based in particular on the intrinsic sense of duty executed in my view and on organization-based processes. Most improvement employees are conscious of cases the place past initiatives can only be located in undertaking buildings, which now serve every other motive or with the assist of piles of rusty machinery, main to continuity session and sustainability. When a community is successful in keeping a company's profit movement for its personal good, it constantly have capability and this improves its superficiality or ego, so they was extra inclined to fear about any agency different than the one that generally didn't exist before.

Community participation includes frameworks for development project (Freudenberg, 2004); understood participation of the community as a key component that helps the managers of the project to identify the ability of the community to implement the development of the projects. The process is conceptualized in a framework that concerns community participation (Goodman, et al., 2008). Thus, it was adapted to the exposure of the developmental problem to the community and reveals the determinants of the ability and capacity of the community to practically construct the efficient solutions.

To ensure project performance, it is very vital to have the project stakeholders participate in the identification of their own needs and drawn plans for the community, focus on the use local and existing skills, knowledge and experience to build the capacity of stakeholders through innovative approach that considers and addresses the common problems (Peter et al., 2013). Therefore, the study conducted by Peter et al., (2013) on participation of community and performance of donor funded project in Michoacan - Mexico indicated that there is a significant positive correlation between joint consultation as predictors of community participation and project performance with 0.781 Pearson correlations and $0.00 \mathrm{p}$-values which is lesser than 0.001 level of significant. Though, it has not clearly outlined on how joint consultation and the project lifecycle that enhances neither community participation nor played role of the stakeholders' participation in consultation process.

Similarly, Minkler et al. (2008) he considered community participation in the initiation of challenges to be imperative due to the fact it reinforced the ability of the local and as a result accelerated the normal well-being of the community. His research about community-based participatory research (CBPR) at 30 environmental problems confirmed that the involvement of residents in physical and environmental problems so shortly grew due to joint consultation which is applied in the project. Specifically, Minkler et al. (2008) mentioned that it was vital to comprise community collaborators at some point in the beginning levels of project due to the fact that it expanded the achievable of the community to become conscious of the problems, to take part in the taking of decisions and translate problems into alternatives or actions. As a result, they placed that participation in the initial section of the obligations helped the local address environmental, health, and social problems thru sensible options.

Performance of export project can be broadly viewed as the outcome of the firms' activities in export project (Ahimbisibwe et al., 2013). Performance of export project defined the firm's degree of economic achievement in its export markets (Kimutai \& Awuor, 2016). Thus, numerous conceptual contributions have indicated the mechanisms applied to attain measures and dimensions of export performance and export strength which is measured as export sales growth, level of export earnings, and volume of export income and export income that contributes to performance of export project (Leonidau, et al., 2002). For the case of this study, performance of fruit export project is measured in terms of welfare improvement, continuous training, and increase of self-help activities in NAEB fruit export project.

\subsection{Research Gap}

Most of the empirical literature has shown that there is a relationship between joint consultation as predictors of community participation and project performance (Peter et al., 2013). Another study conducted by Thwala, (2001) 
stated that community participation for project performance in rural water supply project in South Africa results shown that there is a relationship between community empowerment and project performance, community participation and building beneficiary capacity, increasing project effectiveness and performance. Another study conducted by Abbot (2011) on community participation in development in Johannesburg have revealed that the performance of fruit export project that support in recruiting more villagers to participate in the process of producing more fruit to support market, community empowerment, building beneficiary capacity and project cost sharing.

Previous studies conducted in relation to community participation and performance of project in East Africa, such as the ones conducted in Tanzania and Kenya by (Mnaranara, 2010; Ahimbisibwe et al., 2013; and Kimutai and Awuor, 2016) have revealed that community participation is measured in terms of community mobilization, joint decision, export project increased markets. Performance of export project defined the degree of monetary fulfillment of the company in its export markets. Therefore, there have been many conceptual contributions that are trying to find to achieve measures and dimensions of export overall performance and export energy that is measured as the increase of export sales, the level of export earnings, the quantity of export sales, self-help things, and export profits which commonly contributes to the universal overall performance of exports project (Leonidou et al., 2002).

However, all the previous studies have ignored the community participation and performance of fruit export project. Hence, the need to conduct research on role of community participation in performance of export fruit project in Rwanda. It is also observed that most of the previous studies have ignored to measure community participation with collective decision making, capacity building and joint consultation; and performance of fruit export project measured in terms of welfare improvement, continuous training and increase of self-help activities for performance of fruit export project in Rwanda.

\section{Materials and Methods}

The researcher employed descriptive design to explain the role of community participation and performance of fruit export project fruit export project in Rwanda. This study was conducted in Kamonyi District among 21 project staffs and 395 beneficiaries that increase the number 416 people. Therefore, to select the number of the respondents the formula of Krejce and Morgan (1970) was preferred to have a sample of 144 respondents. The researcher administered a questionnaire to 123 direct project stakeholders who are engaged in project activities to analyze how useful community participation it is for performance of fruit export project while the 21 respondents of the study were given interview.

Data analysis entailed both editing, cleaning, entering and analyzing collected information and employ SPSS version to analyze and produce socio-demographic characteristic descriptive tables and production of descriptive data. The analysis of data used descriptive statistics that comprise the mean, standard deviation, percentages and frequency while the inferential statistics used the correlation analysis and regression analysis tables from regression model $\mathrm{Y}=\beta 0+\beta 1 \mathrm{X} 1+\beta 2 \mathrm{X} 2+\beta 3 \mathrm{X} 3$, whereby $\beta 0$ stands for constant, $\beta 1, \beta 2$, and $\beta 3$ are regression coefficients while $\mathrm{X} 1, \mathrm{X} 2$, and $\mathrm{X} 3$ are predictors of community participation. Therefore, this demonstrated the relationship between community participation and performance of fruit export project in Rwanda. For the case of qualitative data, they were analyzed and be presented in narratives that highlighted direct words from the respondents. Thus, the qualitative data was thematically analyzed into narratives to capture the detailed picture of the situation of in regards to the participation of community and fruit export project performance in Rwanda.

\section{Research Findings}

4.1 Contribution of community empowerment on performance of NAEB fruit export project in Rwanda Table 4. 1: Community Empowerment

\begin{tabular}{llllllll}
\hline $\begin{array}{l}\text { Community } \\
\text { empowerment }\end{array}$ & 5 & 4 & 3 & 2 & 1 & Mean & Std. \\
\hline $\begin{array}{l}\text { I was given training on } \\
\text { methods of plant fruits }\end{array}$ & $2(1.4 \%)$ & $42(29.2 \%)$ & $12(8.3 \%)$ & $33(22.9 \%)$ & $55(38.2 \%)$ & 2.326 & 1.289 \\
$\begin{array}{l}\text { I was give seeds for } \\
\text { planting fruits }\end{array}$ & $1(.7 \%)$ & $4(2.8 \%)$ & $5(3.5 \%)$ & $17(11.8 \%)$ & $117(81.3 \%)$ & 1.298 & 0.729 \\
$\begin{array}{l}\text { I was trained on } \\
\text { selection of right seeds }\end{array}$ & $1(.7 \%)$ & $2(1.4 \%)$ & $3(2.1 \%)$ & $18(12.5 \%)$ & $120(83.3 \%)$ & 1.236 & 0.625 \\
$\begin{array}{l}\text { I was given equipment } \\
\text { to use in fruit }\end{array}$ & $1(.7 \%)$ & $4(2.8 \%)$ & $5(3.5 \%)$ & $15(10.4 \%)$ & $119(82.6 \%)$ & 1.284 & 0.7257 \\
plantation men from the & $1(.7 \%)$ & $2(1.4 \%)$ & $3(2.1 \%)$ & $17(11.8 \%)$ & $121(84.0 \%)$ & 1.229 & 0.622 \\
$\begin{array}{l}\text { I get money from other } \\
\text { project to buy } \\
\text { household necessities }\end{array}$ & & & & & & \\
$\begin{array}{l}\text { I use technology while } \\
\text { communicate to other }\end{array}$ & $1(.7 \%)$ & $3(2.1 \%)$ & $3(2.1 \%)$ & $55(38.2 \%)$ & $82(56.9 \%)$ & 1.513 & 0.709 \\
project stakeholders \\
\begin{tabular}{l} 
Overall Mean \\
\hline
\end{tabular}
\end{tabular}

Source: Primary Data, 2021 
The Table 4.1 presents the Likert scale results whereby 5 stands to no extent, 4 stands for not sure, 3 stands to a small extent, 2 stands to a moderate extent, and 1 stands to a very great extent. The results show that 121 (84.0\%) of respondents stipulated that they got money from the project to other household necessities to a very great extent. The $120(83.3 \%)$ of respondents asserted that they were trained on selection of right seeds to a very great extent, $119(82.6 \%)$ of respondents stated that they were given equipment to use in fruits plantation to a very great extent. The $117(81.3 \%)$ of respondents stipulated that they were given seeds for planting fruits to a very great extent, $82(56.9 \%)$ of respondents asserted that they used technology while communicate to other project stakeholders to a very great extent, and 55 (38.2\%) of respondents stated that they were given training on methods of plant fruits to a very great extent. Hence, the overall mean of 1.481 indicates that beneficiaries of the project participated to a very great extent in community empowerment.

In an interview with a manager at NAEB fruit export project, he stipulated that NAEB fruit export project has started to support the needy to improve their economic status and this project as it kept benefiting from the export of fruits that it has made it has made sure that the benefits reaches all the stakeholders fairly so that they can manage to empower themselves and due to that effect of capacity building and empowerment project now the project has people who can even sponsor the project to start nurseries of new fruit trees. Thus, this shows that empowerment affects the performance of the project.

The results of the study revealed that beneficiaries of the project participated to a very great extent in community empowerment which is supported by the results of the research of Abbot (2011) who revealed that community participation in development affect the performance of fruit export project which support in recruiting more villagers to participate in the process of producing more fruit to support the market, build beneficiary capacity, project cost sharing and empowers the community.

Table 4. 2: Joint Consultation

\begin{tabular}{|c|c|c|c|c|c|c|c|}
\hline Joint consultation & 5 & 4 & 3 & 2 & 1 & Mean & Std. \\
\hline $\begin{array}{l}\text { I participated in project } \\
\text { design }\end{array}$ & $1(.7 \%)$ & $2(1.4 \%)$ & $4(2.8 \%)$ & $13(9.0 \%)$ & $124(86.1 \%)$ & 1.215 & 0.627 \\
\hline $\begin{array}{l}\text { I was involved in } \\
\text { consultative meeting for this } \\
\text { project }\end{array}$ & $10(6.9 \%)$ & $13(9.0 \%)$ & $18(12.5 \%)$ & $25(17.4 \%)$ & $78(54.2 \%)$ & 1.972 & 1.289 \\
\hline $\begin{array}{l}\text { I was involved in needs } \\
\text { identification for this project }\end{array}$ & $7(4.9 \%)$ & $7(4.9 \%)$ & $3(2.1 \%)$ & $12(8.3 \%)$ & $115(79.9 \%)$ & 1.465 & 1.083 \\
\hline $\begin{array}{l}\text { I participated in financing } \\
\text { this project }\end{array}$ & $2(1.4 \%)$ & $4(2.8 \%)$ & $4(2.8 \%)$ & $22(15.3 \%)$ & $112(77.8 \%)$ & 1.347 & 0.787 \\
\hline $\begin{array}{l}\text { I was involved in the } \\
\text { deigning the budget for this } \\
\text { project }\end{array}$ & $18(12.5 \%)$ & $2(1.4 \%)$ & $23(16.0 \%)$ & $92(63.9 \%)$ & $9(6.3 \%)$ & 2.500 & 1.077 \\
\hline $\begin{array}{l}\text { I was involved in } \\
\text { determining project location }\end{array}$ & $4(2.8 \%)$ & $3(2.1 \%)$ & $4(2.8 \%)$ & $10(6.9 \%)$ & $123(85.4 \%)$ & 1.298 & 0.853 \\
\hline Overall Mean & & & & & & 1.632 & \\
\hline
\end{tabular}

Source: Primary Data, 2021

The Table 4.2 presents the Likert scale results whereby 1 represents to a very great extent, 2 represents to moderate extent, 3 represents to small extent, 4 represents not sure and 5 represents to no extent. The 123 (85.4\%) of respondents stipulated that they were involved in determining project location to a very great extent, and 115 (79.9\%) of respondents asserted that they were involved in needs identification for this project to a very great extent. The $112(77.8 \%)$ of respondents stipulated that they participated in financing this project to a very great extent, and $92(63.9 \%)$ of respondents asserted that they were involved in the deigning the budget for this project to a great extent, $78(54.2 \%)$ of respondents stipulated that they were involved in consultative meeting for this project to a very great extent. The mean of 1.632 stands to a very great extent which implies that beneficiaries of the project participated in joint consultation.

The results of this study have shown that beneficiaries of the project participated in joint consultation which is supported by the study of Minkler, et al., (2008) who revealed that community based participatory research involves the residents and joint consultation is made to increase community collaboration in the initiation stage of the project in order to translated problems into alternatives or actions that address local environmental, health, and social project through sensible options. 
4.2 Effect of collective decision making on performance of NAEB fruit export project in Rwanda Table 4. 3: Collective Decision making

\begin{tabular}{llllllll}
\hline Collective decision making & 5 & 4 & 3 & 2 & 1 & Mean & Std. \\
\hline $\begin{array}{l}\text { I participated in the } \\
\text { selection of this project on } \\
\text { behalf of the community }\end{array}$ & $32(22.2 \%)$ & $11(7.6 \%)$ & $17(11.8 \%)$ & $29(20.1 \%)$ & $55(38.2 \%)$ & 2.555 & 1.585 \\
$\begin{array}{l}\text { I decided the distribution of } \\
\text { project benefits for this } \\
\text { project }\end{array}$ & & & & & & \\
$\begin{array}{l}\text { I decided on timeframe for } \\
\text { this project }\end{array}$ & $10(6.9 \%)$ & $14(9.7 \%)$ & $23(16.0 \%)$ & $36(25.0 \%)$ & $61(42.4 \%)$ & 2.138 & 1.260 \\
$\begin{array}{l}\text { I participated in deciding } \\
\text { the budget for this project }\end{array}$ & $1(.7 \%)$ & $1(.7 \%)$ & $1(.7 \%)$ & $9(6.3 \%)$ & $132(91.7 \%)$ & 1.125 & 0.500 \\
$\begin{array}{l}\text { I decided on the community } \\
\text { labor contribution for this } \\
\text { project }\end{array}$ & $1(.7 \%)$ & $1(.7 \%)$ & $1(.7 \%)$ & $6(4.2 \%)$ & $135(93.8 \%)$ & 1.104 & 0.483 \\
$\begin{array}{l}\text { I decided for market } \\
\text { opportunities of this project }\end{array}$ & $8(5.6 \%)$ & $12(8.3 \%)$ & $20(13.9 \%)$ & $17(11.8 \%)$ & $87(60.4 \%)$ & 1.868 & 1.252 \\
Overall mean & & & & & $89(61.8 \%)$ & 2.076 & 1.510 \\
\hline
\end{tabular}

Source: Research Data, 2021

The Table 4.3 presents the Likert scale results whereby 1 stands for strongly agree, 2 for agree, 3 for not sure, 4 for disagree and 5 for strongly disagree. The results demonstrates that $135(93.8 \%)$ of respondents strongly agreed that they decided on the community labor contribution for this project, $132(91.7 \%)$ of respondents strongly agreed that they participated in deciding the budget for this project, $89(61.8 \%)$ of respondents strongly agreed that they decided the distribution of project benefits for this projects, $87(60.4 \%)$ of respondents strongly agreed that they decided for market opportunities of this project, 61 (42.4\%) of respondents strongly agreed that they decided on timeframe for this project, 55 (38.2\%) of respondents strongly agreed that they participated in the selection of this project on behalf of the community. The overall perception stands a mean of 1.811 which is strongly agree hence it implies that beneficiaries of project participated in collective decision making.

In an interview an employee of NAEB fruit project on the issues concerning collective decision making and performance of the project. The interviewee asserted that they take decision concerning the project together with the beneficiaries and other stakeholders. This has improved our production because when they project started has be only involving the managers and some key elements in the project but as they continue to grow the problem also grow together with other developments that they are make that is why they decide to take all the decisions and other concerns of the project in the general meeting and thye discuss them together and find solution which have enhance their performance.

The findings of the study have revealed that beneficiaries of project participated in collective decision making as they are supported by Thwala (2001) which have shown that community participation lays at decision making process, information sharing, consultation and initiation of actions to empower community for project performance.

4.3 Relationship between community participation and performance of NAEB fruit export project in Rwanda

Table 4. 4: Correlation analysis between community participation and performance of NAEB fruit export project fruit export project

\begin{tabular}{|c|c|c|c|c|}
\hline & & $\begin{array}{l}\text { Stakeholder } \\
\text { improvement }\end{array}$ & $\begin{array}{c}\text { welfareStakeholder } \\
\text { satisfaction }\end{array}$ & $\begin{array}{l}\text { Profitability } \\
\text { project }\end{array}$ \\
\hline \multirow{3}{*}{$\begin{array}{l}\text { Community } \\
\text { empowerment }\end{array}$} & Pearson Correlation & $.868^{* *}$ & $.817^{* *}$ & $.826^{* *}$ \\
\hline & Sig. (2-tailed) & .000 & .000 & .000 \\
\hline & $\mathrm{N}$ & 144 & 144 & 144 \\
\hline \multirow{3}{*}{$\begin{array}{l}\text { Collective } \\
\text { making }\end{array}$} & Pearson Correlation & $.862^{* *}$ & $.772^{* *}$ & $.767^{* *}$ \\
\hline & ${ }^{n}$ Sig. (2-tailed) & .000 & .000 & .000 \\
\hline & $\mathrm{N}$ & 144 & 144 & 144 \\
\hline \multirow{3}{*}{ Joint consultation } & Pearson Correlation & $.887^{* *}$ & $.975^{* *}$ & $.907^{* *}$ \\
\hline & Sig. (2-tailed) & .000 & .000 & .000 \\
\hline & $\mathrm{N}$ & 144 & 144 & 144 \\
\hline
\end{tabular}

**. Correlation is significant at the 0.01 level (2-tailed).

Source: Primary Data, 2021 
The findings in Table 4.4 proves that there is a relationship between community empowerment and stakeholder welfare improvement $(\mathrm{r}=0.868$ and $\mathrm{sig}=0.00)$, between community empowerment and stakeholder satisfaction $(\mathrm{r}=0.817$ and $\operatorname{sig}=0.00)$, between community empowerment and profitability of project $(\mathrm{r}=0.826$ and $\mathrm{sig}=0.00)$, between collective decision making and stakeholder welfare improvement ( $\mathrm{r}=0.862$ and sig=0.00) between collective decision making and stakeholder satisfaction $(r=0.772$ and $s i g=0.00)$ between collective decision making and profitability of project $(\mathrm{r}=0.767$ and $\mathrm{sig}=0.00)$ between joint consultation and stakeholder welfare improvement $(\mathrm{r}=0.887$ and $\mathrm{sig}=0.00)$ between joint consultation and stakeholder satisfaction $(\mathrm{r}=0.975$ and sig=0.00) between joint consultation and profitability of project ( $\mathrm{r}=0.907$ and sig=0.00) since the calculated Pearson correlation are positive and strong whereas the calculated significance levels are less than 0.01 significance level. Hence, community participation has a positive and significance relationship with performance of NAEB fruit export project in Rwanda.

The results of community participation and performance of project has shown positive and significant relationship which are supported by the findings of the study of Peter et al., (2013) who proved a significant positive correlation between joint consultation as predictor of community participation and performance of donor funded project with 0.781 Pearson correlation and 0.00 p-values which is lesser than 0.001 level of significance.

\section{5: Coefficients of community participation and stakeholder satisfaction}

\begin{tabular}{llllll}
\hline Model & \multicolumn{2}{l}{ Unstandardized Coefficients } & $\begin{array}{l}\text { Standardized } \\
\text { Coefficients }\end{array}$ & & S \\
\cline { 2 - 5 } & $\mathrm{B}$ & Std. Error & Beta & \\
\hline (Constant) & .016 & .016 & & -1.001 & .319 \\
Community empowerment & 1.314 & .074 & 1.251 & 17.679 & .000 \\
Collective decision making & 1.123 & .067 & 1.144 & 16.784 & .000 \\
Joint consultation & .827 & .017 & .868 & 49.204 & .000 \\
\hline
\end{tabular}

a. Dependent Variable: Stakeholder satisfaction

Source: Research Data, 2021

The Table 4.5 show that community participation has a positive effect on the progress of stakeholder satisfaction in NAEB fruit project as shown by the regression model $Y=\beta 0+\beta 1 X 1+\beta 2 X 3+\beta 3 X 3+\varepsilon$ which became $\mathrm{Y}=0.016+1.314 \mathrm{X} 1+1.123 \mathrm{X} 3+0.827 \mathrm{X} 3$ and the calculated significance levels which are less than 0.05 level of significance. The coefficients of community empowerment and stakeholder satisfaction $(b=1.314$ and sig=0.00), collective decision making and stakeholder satisfaction $(b=1.123$ and sig=0.00), joint consultation and stakeholder satisfaction $(b=0.827$ and $\operatorname{sig}=0.00)$ proving that community participation and stakeholder satisfaction has a positive and significant relationship in NAEB fruit project in Rwanda.

The results of the study revealed a positive significant relationship between community participation and stakeholder satisfaction which is supported by the results of the study of Goodman et al., (2008) who asserted that community participation affect the community's ability of capacity to construct practical and efficient solutions. Thus, there is nothing that can have effect on another when they don't have relationship meaning nothing in isolation that can be affected by interaction of others. In this case the practical and efficient solutions are meant to enhance performance of the project in the case of the current study.

Table 4. 6: Coefficients of community participation and stakeholder welfare improvement

\begin{tabular}{|c|c|c|c|c|c|}
\hline \multirow[t]{2}{*}{ Model } & \multicolumn{2}{|c|}{ Unstandardized Coefficients } & \multirow{2}{*}{$\begin{array}{l}\text { Standardized } \\
\text { Coefficients } \\
\text { Beta }\end{array}$} & \multirow[t]{2}{*}{$\mathrm{t}$} & \multirow[t]{2}{*}{ Sig. } \\
\hline & $\mathrm{B}$ & Std. Error & & & \\
\hline (Constant) & .047 & .047 & & 1.001 & .319 \\
\hline Community empowerment & .059 & .223 & .057 & .265 & .031 \\
\hline Collective decision making & .370 & .201 & .379 & 1.844 & .017 \\
\hline Joint consultation & .518 & .050 & .546 & 10.265 & .000 \\
\hline
\end{tabular}

a. Dependent Variable: Stakeholder welfare improvement

Source: Primary Data, 2021

The Table 4.6 show that community participation has a positive effect on the progress of stakeholder welfare improvement in NAEB fruit project as shown by the regression model $Y=\beta 0+\beta 1 X 1+\beta 2 \times 3+\beta 3 \times 3+\varepsilon$ which became $\mathrm{Y}=0.047+0.059 \mathrm{X}_{1}+0.370 \mathrm{X}_{3}+0.518 \mathrm{X}_{3}$ and the calculated significance levels which are less than 0.05 level of significance. The coefficients of community empowerment and stakeholder welfare improvement $(b=0.059$ and $\mathrm{sig}=0.031)$, collective decision making and stakeholder welfare improvement $(b=0.370$ and sig=0.017), joint consultation and stakeholder welfare improvement $(b=0.518$ and sig=0.00) proving that community participation and stakeholder welfare improvement has a positive and significant relationship in NAEB fruit project in Rwanda.

The results of the study have shown a positive and significant relationship between community participation and stakeholder welfare improvement which is supported by the results of the study of Kashish and Vikrant (2017) 
who asserted that that customers satisfaction and value increase affect positively the performance of market in business products through market intelligence which increase the profitability of the project and their welfare. Though, the results of the study of Kashish and Vikrant (2017) have given less attention the community participation in affecting stakeholder welfare improvement but their results show that customer satisfaction increase market performance which in turn improves the welfare of the beneficiaries of the project.

Table 4. 7: Coefficients of community participation and profitability of project

\begin{tabular}{llllll}
\hline Model & \multicolumn{2}{l}{ Unstandardized Coefficients } & \multicolumn{2}{c}{$\begin{array}{l}\text { Standardized } \\
\text { Coefficients }\end{array}$} & \multicolumn{2}{c}{ Sig. } \\
\cline { 2 - 5 } & $\mathrm{B}$ & Std. Error & Beta & \\
\hline (Constant) & .008 & .033 & & .232 & .817 \\
Community empowerment & 2.151 & .155 & 2.109 & 13.860 & .000 \\
Collective decision making & 1.738 & .140 & 1.821 & 12.428 & .000 \\
Joint consultation & .596 & .035 & .643 & 16.962 & .000 \\
\hline
\end{tabular}

a. Dependent Variable: Profitability of project

Source: Research Data, 2021

The Table 4.17 shows that community participation has a positive effect on the progress of profitability in NAEB fruit project as shown by the regression model $Y=\beta 0+\beta 1 X 1+\beta 2 X 3+\beta 3 X 3+\varepsilon$ which became $\mathrm{Y}=0.008+2.151 \mathrm{X} 1+1.738 \mathrm{X} 3+0.596 \mathrm{X} 3$ and the calculated significance levels which are less than 0.05 level of significance. The coefficients of community empowerment and project profitability $(b=2.151$ and $\operatorname{sig}=0.00)$, collective decision making and project profitability $(b=1.738$ and sig=0.00), joint consultation and project profitability $(b=0.596$ and $\mathrm{sig}=0.00)$ proving that community participation and project profitability has a positive and significant relationship in NAEB fruit project in Rwanda.

This study confirms a positive and significant relationship between community participation and profitability of project which is supported by the findings of the study of Thwala (2010) whose findings have revealed a relationship between community empowerment and project performance, community participation and building beneficiary capacity and increase project effectiveness and its performance.

\subsection{Conclusion}

In conclusion, the results of the first objective of the study concerning the community empowerment and performance of NAEB fruit export project have shown an overall mean of 1.481. Hence, it implies that community empowerment contributes to performance of NAEB fruit export project. The results have also indicated that joint consultation affects performance of NAEB fruit export project in Rwanda which is confirmed by the score of an overall mean of 1.631 which also implies that community participate in enhance the performance of the project not only as the beneficiaries of the project but also as the consultants of the project where joint consultation facilitate them to participate in performance of NAEB fruit export project in Rwanda.

The results of the second objective of the study regarding the effect of collective decision making and performance of NAEB fruit export project have revealed that the overall perception of 1.811 confirms that the effect of collective decision making on performance of NAEB fruit export project. The results of the study indicated that an overall mean of 1.504 demonstrates that stakeholder welfare was improved due the performance of NAEB fruit export project. The results of the study have also revealed that the overall mean of

1.408 which affirms that stakeholder satisfaction was attained due to performance of NAEB fruit export project.

The objective three prove that community participation and performance of NAEB fruit export project has a positive and significance relationship because the relationship between the predictors and determinants of community participation and project performance respectively has shown strong and positive correlation and calculate significance which is lesser than 0.01 level of significance. Thus, for instance the relationship between community empowerment and stakeholder welfare improvement ( $\mathrm{p}=0.868$ and sig=0.00), between joint consultation and stakeholder satisfaction $(\mathrm{r}=0.975$ and sig=0.00), and between joint consultation and profitability of project $(r=0.907$ and $\operatorname{sig}=0.00)$ proving that community participation plays a positive and significant role in enhancing the performance of NAEB fruit export project in Rwanda.

\subsection{Acknowledgement}

I firstly thank God for protection and life through my studies and during compilation of this research project. Appreciations should go to my lovely wife and daughter who has been the source of energy during the compilation of this research project. The academic staff and non- academic staff of Mount Kenya University Rwanda deserve a lot of appreciation for making the academic environment so smooth and enjoyable for me. I particularly thank my lecturers who taught me in class and made who I am today. I also appreciate the contribution of my colleagues during classes and my workmates who were always ready to give me information regarding school and work so that everything went on well. I can never forget the contribution of NAEB fruit project in providing to me the primary data and respondents who were the source of all of the information used in this research project. God bless you all. 


\section{References}

[1].Ahimbisibwe, G. M., Ntayi, J. M., \& Ngoma M. (2013). Export community participation, innovation and performance of fruit exporting firms in Uganda. European Scientific Journal, 12 (6), 34-36.

[2].Alyse, L \& Akehur, L.C (2003). Lifelong learning through SMEs: Exploring workplace learning in the UK. Journal of Workplace Learning, 23(5),331-348.

[3].Cleaver, F. (2009). Rethinking agency, rights and natural resource management, in Mitlin, D. and Hickey, S. (Eds.), Rights-based approaches to development: Exploring the potential and pitfalls. Kumarian Press, Sterling, VA.

[4].Freudenberg, N. (2004). Community Health Services for Returning Jail and Prison Inmates. Journal of Correctional Health Care, 4(3), 16-34.

[5].Goodman, M; Squibb, K; Youngstrom, E; Anthony, LG; Kenworthy, L; Lipkin, PH; Mattison, DR; Lakind, JS. (2008). Using systematic reviews and meta-analyses to support regulatory decision-making for neurotoxicants: Lessons learned from a case study of PCBs. Journal of Environmental Health Perspective, 118 (3), 727-734.

[6].Kai, A.S., \& Greenwood, J.D. (2003) Promises and Dilemmas of Participation: Action Research, Search Conference Methodology, and Community Development, Journal of the Community Development Society, 34:1, 18-35, DOI: 10.1080/15575330309490101.

[7].Kashish, A. \& Vikrant, D. (2017). A study on production and trade performance of fruits in India. Department of Economics and Sociology. Punjab Agricultural University. Ludhiana. India

[8].Kimutai, Y.J \& Awuor, E. (2016). Community participation and Performance of Fruit Exporting Firms in Kenya: A theoretical Perspective. European Journal of Business and Management. 8 (9), 12-23.

[9].Krejcie, R.V., \& Morgan, D.W. (1970). Determining Sample Size for Research Activities. Journal of Educational and Psychological Measurement, 30, 607-610

[10]. Leonidau, T., Lopo L., R., Matthew T., Billett, \& Neil A (2002). American Marketing Association. Consumer- Based Brand Equity and Firm Risk. Journal of Marketing, 73 (2), 55-70.

[11]. Minkler, M, Wallerstein, N., Glanz K, Lewis FM, Rimer BK (2008). Community-based participatory research for health: from process to outcomes (2nd ed.). San Francisco: Jossey-Bass

[12]. Mnaranara, T. (2010). The importance of community participation in an ongoing constructions of primary schools. A case study of Mlali and Mazumbe ward, Unpublished master's thesis at University of Agder. Retrieved at http://hdl.handle.net/11250/135155

[13]. Peter, G., George, T., Kirui, K. \& Luvega, C. (2013). The Dilemma in sustainability of Community Based Approach. Global Journal of Advanced Research, 2(4), 757-768.

[14]. Samah, M. \& Aref, F. (2009). Assessing the Level of Community Participation as a Component of Community Capacity Building for Tourism Development. European Journal of Social Sciences 8(1):68-75

[15]. Thwala W. D. (2010). Community participation is a necessity for project performance: A case study of rural water supply project in Jeppes Reefs, South Africa. African Journal of Agricultural Research, 5(10), 970979, DOI: 10.5897/AJAR09.700

[16]. Thwala, WDA (2001). Critical Evaluation of Large-Scale Development Projects and Programmes in South Africa 1980-1994. Unpolished Master's thesis, University of the Witwatersrand

[17]. Wanjohi, A. M. (2010). Challenges Facing SMEs in Kenya and the Efforts in Progress. SME PAPERS. Retrieved at http://www.kenpro.org/challenges-facingSMEs-in-Kenya-and-the-efforts-in-progress/ on 10 June 2021 